\section{Risikofaktorer for abdominalt aortaaneurisme}

\author{
Kardiovaskulære sykdommer og abdominale aortaaneurismer har \\ felles risikofaktorer. Det viser resultater fra Troms $\varnothing$-unders $\varnothing$ kelsen \\ $1994-2001$
}

Ruptur av abdominalt aortaaneurisme har høy mortalitet og er årsak til $1-2 \%$ av dødsfallene i den vestlige verden. De fleste aneurismene oppdages tilfeldig, og det har vært foreslått å screene risikogrupper for å redusere dødeligheten.

For å kartlegge prevalensen av abdominalt aortaaneurisme og mål på aortas diameter ble det i den fjerde Tromsø-undersøkelsen gjort ultralydundersøkelse av abdominalaorta hos 6892 menn og kvinner i alderen 25-82 år (1). Den samme populasjonen ble undersøkt sju år senere (2). I gruppen av til sammen 2035 menn og 2310 kvinner som møtte til begge undersøkelsene og som ikke hadde abdominalt aortaaneurisme i 1994, ble det funnet 119 insidente abdominale aortaaneurismer, noe som tilsvarer en insidens på $0,4 \%$ per år. Det ble påvist aneurisme hos $4,1 \%$ av mennene og $1,5 \%$ kvinnene. Studien er blitt omtalt på lederplass i Circulation (3).

- Mannlig kjønn, høy alder og røyking er sterke risikofaktorer for abdominalt aortaaneurisme, men også forhøyet kolesterolnivå, lavt HDL-nivå og hypertensjon var signifikante faktorer. Røyking slo særlig sterkt ut - både med antall år som røyker og antall sigaretter per dag økte risikoen for abdominalt aortaaneurisme, sier førsteforfatter Signe Helene Forsdahl ved Institutt for samfunnsmedisin, Universitetet i Tromsø.

- Studien viser at det er en sterk sammenheng mellom tradisjonelle risikofaktorer for aterosklerose og risikoen for å utvikle abdominalt aortaaneurisme. Resultatene kan være til hjelp for å finne dem som har for-

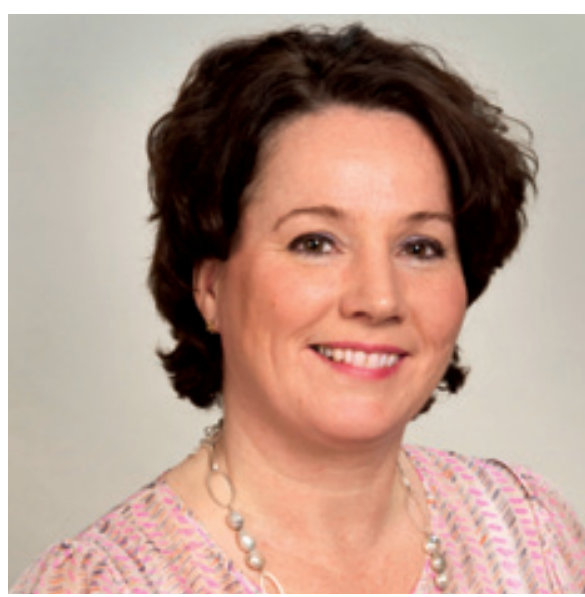

Signe Helene Forsdahl, artikkelens førsteforfatter. Foto Bjørn-Kåre Iversen, Det helsevitenskapelige fakultet, Universitetet i Tromsø

høyet risiko for å utvikle slike aneurismer og for å avklare hvilke grupper som eventuelt bør screenes, sier Forsdahl.

\section{Erlend Hem \\ erlend.hem@medisin.uio.no \\ Tidsskriftet \\ Litteratur \\ . Singh K, Bønaa KH, Jacobsen BK et al. Prevalence of and risk factors for abdominal aortic aneurysms in a population-based study: the Troms $\varnothing$ Study. Am J Epidemiol 2001; 154: 236-44. \\ 2. Forsdahl SH, Singh K, Solberg $S$ et al. Risk factors for abdominal aortic aneurysms: a 7-year pro spective study: the Tromsø Study, 1994-2001. Circulation 2009: 119: 2202-8. \\ 3. Diehm N, Baumgartner I. Determinants of aneu- rysmal aortic disease. Circulation 2009; 119 $2134-5$.}

\section{Ordforklaringer}

Tromsø-undersøkelsen ble startet i 1974 på bakgrunn av den høye dødeligheten av hjerte- og karsykdommer i Norge. Det har vært gjennomført seks undersøkelser hvor til sammen 40051 personer har deltatt i minst én av dem. Man har særlig konsentrert seg om kardiovaskulære sykdommer | 1994-95 (Tromsø 4) ble det for første gang utført ultralydundersøkelse av abdominalaorta for å kartlegge prevalens og risikofaktorer for abdominalt aortaaneurisme. Undersøkelsen ble gjentatt sju år senere i den samme populasjonen (Troms $\varnothing$ 5) med tanke på å kartlegge aneurismets utvikling og endringer i aortas diameter.

Abdominale aortaaneurismer forårsaker omtrent $1 \%$ av alle dødsfall i den vestlige verden. Aneurismene er vanligvis asymptomatiske inntil de rumperer. De fleste oppdages tilfeldig i forbindelse med rutineundersøkelser for andre tilstander. Risikoen for ruptur øker med økende aneurismediameter. Ved rumpert aneurisme er mortaliteten 60-80\%. Både genetiske, miljømessige, hemodynamiske og immunologiske faktorer bidrar trolig til utvikling av slike aneurismer.
Er du i ferd med å publisere eller har du nylig publisert i et internasjonalt tidsskrift? Send tips til erlend.hem@medisin.uio.no

www.tidsskriftet.no/norskforskning

\title{
Tromsø-undersøkelsen
}

\section{Artikkelen er skrevet av fire norske forskere.}

Førsteforfatter Signe Helene Forsdahl er lege med bakgrunn fra Radiologisk avdeling ved Universitetssykehuset Nord Norge. Hun er nå ph.d.-student ved Institutt for samfunnsmedisin, Universitetet i Tromsø. Hennes hovedveileder er Bjarne Koster Jacobsen, som er professor i epidemiologi. Biveileder er seksjonsoverlege Kulbir
Singh ved Radiologisk avdeling. Steinar Solberg er overlege ved Thoraxkirurgisk avdeling, Oslo universitetssykehus, Rikshospitalet. Han har sammen med Kulbir Singh designet og gjennomført delstudien om aortaaneurismer i Tromsø-undersøkelsen.
Artikkelen ble publisert 28.4. 2009 i Circulation, som er det høyest rangerte tidsskriftet innen kardiologi 